\title{
PENGARUH KEPEMIMPINAN DAN KOMUNIKASI KERJA TERHADAP KINERJA ASN (STUDI KASUS DI 4 KECAMATAN) KOTA LUBUKLINGGAU
}

\author{
Yulpa Rabeta ${ }^{1}$ \\ ${ }^{1}$ Program Studi Manajemen, Universitas Bina Insan Lubuklinggau \\ E-mail : ${ }^{1}$ yulpa raberta@univbinainsan.ac.id
}

\begin{abstract}
ABSTRACK
The lack of leader strategy in communicating well to ASN, the lack of leadership attitude in giving attention and motivating ASN work and the lack of work communication among fellow employees resulted in less than optimal ASN performance. This research was conducted to determine the Effect of Leadership and Work Communication on ASN Performance (Case Studies in 4 Sub-Districts) of Lubuklinggau City. Data collection techniques in this study used a questionnaire method. Using SPSS 17.0 Program assistance. Data analysis techniques used are Multiple Linear Regression Analysis, Determination Coefficient $\left(R^{2}\right)$, and Test $F$. From the results of the Multiple Regression Analysis obtained the equation $\hat{Y}=0.448+0.617 X_{1}+0.379 X_{2}$. Furthermore, from the determinant analysis obtained $R$ square value $\left(R^{2}\right)$ of 0.867 or $86.7 \%$. This value gives the meaning that Leadership $\left(X_{1}\right)$ and Work Communication $\left(X_{2}\right)$ contributed an influence of $86.7 \%$ on ASN (Y) Performance. While the remaining $13.3 \%$ is influenced by other variables not included in this study. Based on the Anova calculation ( $F$ test), it is seen that the $F_{\text {count }}$ value is 169,645 with a significant level of 0,000 while $F_{\text {table }}$ with $\alpha=5 \%$ and (nk-1) or (55$2-1)=52$. And the numerator $(k-2)$ is 3,175. $F_{\text {count }}(169,645)>F_{\text {table }}(3,175)$, meaning Ho is rejected and Ha is accepted. This shows that there is a significant influence between Leadership and Work Communication on ASN Performance.
\end{abstract}

Keywords : Leadership, Work Communication, ASN Performance

\begin{abstract}
ABSTRAK
Kurangnya startegi pemimpin dalam berkomunikasi baik dengan ASN, masih kurangnya sikap pimpinan dalam memberikan perhatian dan memotivasi kerja ASN, dan kurangnya komunikasi kerja antar pegawai mengakibatkan kinerja ASN kurang maksimal.Penelitian ini dilakukan untuk mengetahui Pengaruh Kepemimpinan dan Komunikasi Kerja Terhadap Kinerja ASN (Studi Kasus di 4 Kecamatan) Kota Lubuklinggau. Teknik pengumpulan data dalam penelitian ini digunakan metode kuisioner).Menggunakan bantuan Program SPSS 17.0. Tekhnik analisis data yang digunakan adalah Analisis Regresi Linier Berganda, Koefisien Determinasi $\left(\mathrm{R}^{2}\right)$, dan Uji F. Dari hasil Analisi Regresi Berganda diperoleh persamaan $\hat{Y}=0,448+0,617 \mathrm{X}_{1}+$ $0,379 \mathrm{X}_{2}$. Selanjutnya dari analisis Determinan diperoleh nilai $\mathrm{R}$ square $\left(\mathrm{R}^{2}\right)$ sebesar 0,867 atau $86,7 \%$. Nilai tersebut memberi makna bahwa Kepemimpinan $\left(\mathrm{X}_{1}\right)$ dan Komunikasi Kerja $\left(\mathrm{X}_{2}\right)$ memberikan sumbangan pengaruh sebesar $86,7 \%$ terhadap Kinerja ASN (Y). Sedangkan sisanya sebesar 13,3\% dipengaruhi oleh variabel lain yang tidak masuk dalam penelitian ini. Berdasarkan hasil perhitungan Anova (Uji F), terlihat bahwa nilai $F_{\text {hitung }}$ adalah sebesar 169,645 dengan tingkat signifikan 0,000 sedangkan $\mathrm{F}_{\text {tabel }}$ dengan $\alpha=5 \%$ dan $(\mathrm{n}-\mathrm{k}-1)$ atau $(55-2-1)=52$. Serta pembilang (k-2) adalah sebesar 3,175. $F_{\text {hitung }}(169,645)>F_{\text {tabel }}(3,175)$, artinya Ho ditolak dan Ha diterima.Hal ini menunjukkan ada pengaruh yang signifikan antara Kepemimpinan dan Komunikasi Kerja terhadap Kinerja ASN.
\end{abstract}

Kata kunci : Kepemimpinan, Komunikasi Kerja, Kinerja ASN 


\section{PENDAHULUAN}

Sumber Daya Manusia (SDM) dalam suatu organisasi memiliki kedudukan yang penting pada pelaksanaan proses kerja organisasi dalam pencapaian tujuan. Manusia dalam organisasi menjadi elemen utama dibandingkan dengan sumber daya yang lain. Sumber daya manusia yang merancang dan merumuskan seluruh strategi tujuan organisasi.

Kecamatan adalah pembagian wilayah administratif di Indonesia di bawah kabupaten atau kota yang terdiri atas desadesa atau kelurahan. Dalam konteks otonomi daerah di Indonesia, kecamatan merupakan Satuan Kerja Perangkat Daerah (SKPD) kabupaten atau kota yang mempunyai wilayah kerja tertentu yang dipimpin oleh seorang Camat. Ada beberapa kecamatan yang ada di Kota Lubuklinggau diantaranya Kecamatan Selatan I, Kecamatan Selatan II, Kecamatan Timur I, dan Kecamatan Timur II.

Kecamatan yang dipimpin oleh seorang Camat yang bertanggung jawab kepada Bupati atau Wali kota melalui perantaraan seorang Sekretaris Daerah. Ada beberapa unsur yang terdapat di dalam sutu kecamatan, antara lain : Camat, Sekretaris Kecamatan, serta beberapa seksi dan beberapa sub bagian di bawahnya.

Organisasi dituntut untuk mampu meningkatkan kualitas SDM yang ada. Kualitas SDM tersebut banyak ditentukan oleh sejauh mana sistem yang ada di dalam sebuah organisasi sehingga mampu menunjang dan memuaskan keinginan baik dari pegawai maupun dari organisasi.

Keberhasilan suatu organisasi sangat dipengaruhi oleh kinerja pegawainya. Kinerja merupakan hasil atau tingkat keberhasilan seseorang secara keseluruhanselama periode tertentu di dalam melaksanakan tugas dibandingkan denganberbagai kemungkinan, seperti standar hasil kerja, target atau sasaran atau kriteria yangtelah disepakati bersama.
Kasmir

(2018:182)

kinerja

merupakan hasil kerja dan perilaku kerja yang telah dicapai dalam menyelesaikan tugas-tugas dan tanggung jawab yang diberikan dalam suatu periode tertentu.

Mencapai tujuan organisasi yang optimal, diperlukan peningkatan kinerja pegawai, adapun faktor-faktor yang mempengaruhi kinerja pegawai diantaranya adalah kepemimpinan dan komunikasi kerja.

Busro (2018:218) kepemimpinan adalah suatu proses memengaruhi orang lain, hingga orang lain tersebut dengan sukarela mau melaksanakan kegiatan bersama dalam rangka mencapai tujuan yang telah ditentukan.

Kinerja pegawai juga dipengaruhi oleh komunikasi kerja, Mangkunegara (2016:145) komunikasi adalah proses pemindahan suatu informasi, ide, pengertian dari seseorang kepada orang lain dengan harapan orang lain tersebut dapat menginterpretasikannya sesuai dengan tujuan yang dimaksud.

Komunikasi melibatkan individuindividu dalam suatu hubungan kelompok, organisasi, dan masyarakat yang merespon dan menciptakan pesan untuk beradaptasi denganlingkungan satu sama lain. Kompetensi komunikasi yang baik antar karyawanakan mampu memperoleh dan mengembangkan tugas yang diembannya, sehinggatingkat kinerja suatu perusahaan menjadi semakin baik dan sebaliknya.

Komunikasi dalam suatu organisasi merupakan faktor yang sangat penting dalammenjalani interaksi antara satu dengan yang lainnya, apabila tidak adanya suatu komunikasi seluruh individu dalam organisasi tersebut tidak dapat mengetahui apa yang harus mereka lakukan untuk organisasinya, pemimpin tidak dapat menerima masukan informasi dan para penyedia tidak dapat memberikan instruksi.

Kecamatan merupakan unsur pelaksana administrasi dalam melayani masyarakat. Adapun pelayanan yang di 
berikan oleh pegawai pada 4 Kantor Camat di Lubuklinggau yaitu di pengurusan kartu keluarga (KK) surat pengantar KTP, izin keramaian pendapatan penduduk dan adminitrasi lainya.

Perkerjaan ini tidak didukung oleh kinerja yang baik, kurangnya startegi pemimpin dalam berkomunikasi baik dengan ASN, masih kurangnya sikap pimpinan dalam memberikan perhatian dan memotivasi kerja ASN, dan kurangnya komunikasi kerja antar pegawai mengakibatkan kinerja ASN kurang maksimal. Oleh karena itu masyarakat akan kecewa serta dapat menimbulkan kurangnya rasa kepercayaan terhadap pemerintah.

Penelitian ini dilakukan untuk mengetahui Pengaruh Kepemimpinan dan Komunikasi Kerja Terhadap Kinerja ASN (StudiKasus di 4 Kecamatan) Kota Lubuklinggau.

\section{TINJAUAN PUSTAKA}

\subsection{Kinerja}

Menurut Wibowo (2016:7) kinerja merupakan hasil pekerjaan yang mempunyai hubungan kuat dengan tujuan strategis organisasi, kepuasan konsumen, dan memberikan kontribusi pada ekonomi.

\section{Menurut Sutrisno}

(2016:152)

prinsip-prinsip dasar kinerja adalah sebagai berikut :

1. Hasil kerja

Tingkat kuantitas maupun kualitas yang telah dihasilkan dan sejauh mana pengawasan dilakukan.

2. Pengetahuan pekerjaan

Tingkat pengetahuan yang terkait dengan tugas pekerjaan yang akan berpengaruh langsung terhadap kuantitas dan kualitas dari hasil kerja.

3. Inisiatif

Tingkat inisiatif selama melaksanakan tugas pekerjaan.

4. Kecekatan mental

Tingkat kemampuan dan kecepatan dalam menerima instruksi kerja.
5. Sikap

Tingkat semangat kerja serta sikap positif dalam melaksanakan pekerjaan.

6. Disiplin waktu dan absensi

Tingkat kecepatan waktu dan tingkat kehadiran.

Menurut Fahmi (2014:228) fungsifungsi kinerja adalah sebagai berikut :

1. Mendukung misi jauh manajemen kualitas total.

2. Membantu memberikan wewenang kepada orang memberi orang lebih banyak ruang lingkup untuk bertanggung jawab atas pekerjaan dan melaksanakan kontrol atas pekerjaan itu.

3. Membantu mempertahankan orang-orang yang mempunyai kualitas yang tinggi.

4. Memungkinkan individu mengembangkan kemampuan mereka dan meningkatkan.

5. Mengembangkan hubungan yang konstruksi dan terbuka antara individu dan manajer dalam suatu proses dialog yang dihubungkan dengan pekerjaan yang sedang dilaksanakan sepanjang tahun.

Menurut Kasmir (2018:183) adapun tujuan kinerja antara lain :

1. Sebagai kapasitas untuk melakukan Yaitu yang berkaitan dengan derajat hubungan proses dalam individu yang relevan antara tugas dan keahlian, kemampuan, pengetahuan dan pengalaman.

2. Sebagai kesempatan untuk melakukan Yaitu yang berkaitan dengan ketersediaan peralatan dan teknologi.

3. Sebagai kerelaan untuk melakukan Yaitu yang berhubungan dengan hasrat dan kerelaan untuk menggunakan usaha mencapai kinerja.

Menurut Siagian (2016:234) metode

kinerja adalah sebagai berikut :

1. Metode skala peringkat yaitu metode yang bersifat subjektif.

2. Metode checklist yaitu berkaitan bobot nilai. 
3. Metode pilihan terarah yang berkaitan dengan pernyataan dari pimpinan.

4. Metode insiden kritikal yaitu berkaitan dengan peristiwa yang terjadi.

5. Metode skala peringkat yang dikaitkan dengan perilaku.

6. Metode evaluasi lapangan yaitu berkaitan dengan prestasi kerja pegawai.

7. Metode tes dan observasi berkaitan uji kemampuan kinerja pegawai.

8. Metode pendekatan-pendekatan yang bersifat komparatif

Menurut Kasmir (2018:87) adapun tahapan kinerjaantaralain :

1. Kualitaskeluaran

2. Jangkawaktu yang dibutuhkan

3. Kehadiranditempatkerja

4. Sikapkooperatif di dalamorganisasi

Menurut Sutrisno (2016:151) faktorfaktor yang memengaruhi kinerja adalah :

1. Usaha (Effort)

Yang menunjukkan sejumlah sinergi fisik dan mental yang digunakan dalam menyelenggarakan gerakan tugas.

2. Kemampuan (Abilities)

Yang berhubungan sifat-sifat rasional yang diperlukan untuk melaksanakan suatu tugas.

3. Peran atau Persepsi Tugas (Role or Task Perception)

Yaitu segala perilaku dan aktivitas yang dirasa perlu oleh individu untuk menyelesaikan suatu pekerjaan.

\subsection{Kepemimpinan}

Menurut Suwatno dan Juniarsih (2016:164) kepemimpinan adalah sebagai kemampuan dan kekuatan seseorang pemimpin untuk mempengaruhi pikiran orang lain agar mau dan mampu mengikuti kehendaknya, dan memberi inspirasi kepada pihak lain untuk merancang sesuatu yang lebih bermakna.

Menurut Busro (2016:167) dilihat dari aspeknya adapun prinsip-prinsip dasar kepemimpinan adalah sebagai berikut :

1. Dari aspek kepribadian (Personality)
Yaitu untuk menjalankan tugas dengan sebaik-baiknya dituntut persyaratan kepribadian yang mantap dan menunjukkan moralitas yang baik.

2. Dari aspek kemampuan(Skill)

Yaitu untuk menjalankan tugas dan mencapai tujuan organisasi harus ditunjang dengan kemampuan, seperti : keterampilan manajerial (Manajerial skill), keterampian konsep (Conceptual skill), keterampilan hubungan insani (Human relations skill), keterampilan teknis (Technical skill), keterampilan dalam proses kelompok, dan keterampilan dalam implementasi bidang-bidang manajemen

Menurut Priansa dan Sule (2018:19) metode kepemimpinan adalah :

1. Memberikan perintah dan memberikan celaan serta pujian

2. Memupuk tingkah laku pribadi yang benar

3. Peka terhadap saran-saran

4. Memperkuat rasa kesatuan kelompok

5. Mengembangkan rasa tanggung jawab di kalangan masyarakat

6. Membuat keputusan yang bernilai dan tepat pada waktunya

Menurut Priansa dan Suwatno (2018:152) adapun tahapan kepemimpinan adalah sebagai berikut :

1. Energi

Yaitu mempunyai kekuatan mental dan fisik.

2. Stabilitas emosi

Yaitu tahapan dimana seorang pimpinan tidak boleh berburuk sangka terhadap bawahannya, dan tidak boleh cepat marah serta percaya pada diri sendiri harus cukup besar.

3. Human relations

Yaitu mempunyai pengetahuan tentang hubungan manusia.

4. Personal motivations

Yaitu keinginan untuk menjadi pemimpin harus besar, dan dapat memotivasi diri sendiri. 
5. Teaching skill

Yaitu mempunyai kecakapan untuk mengajarkan, menjelaskan dan mengembangkan bawahannya.

6. Communacition skill

Yaitu mempunyai kecakapan untuk berkomunikasi.

7. Social skill

Yaitu mempunyai keahlian di bidang sosial, supaya menjamin kepercayaan dan kesetian bawahannya.

8. Technical competent

Yaitu mempunyai kecakapan menganalisa, merencanakan, mengorganisasikan, mendelegasikan wewenang, mengambil keputusan dan mampu menyusun konsep.

Menurut Busro (2018:235) adapun faktor-faktor yang memengaruhi kepemimpinan adalah sebagai berikut :

1. Kepribadian (Personality)

Yaitu meliputi kemampuan beradaptasi, kesiagaan, kreativitas, dan keseimbangan pribadi.

2. Kecerdasan (Intelegence)

Yaitu meliputi pertimbangan, dan ketegasan mengambil keputusan.

3. Kemampuan (Ability)

Yaitu meliputi kemampuan menumbuhkan kerja sama dan partisipasi sosial.

\subsection{Komunikasi Kerja}

Menurut Silalahi (2015:270)

komunikasi kerja adalah suatu kegiatan mengirim (sending) dan menerima (receiving) pesan melalui media.Pengiriman pesan berkaitan dengan makna pesan dan penerimaan pesan berkaitan dengan pemahaman atas pesan.

Menurut Muhammad (2015:19) adapun prinsip-prinsip dasar komunikasi kerja adalah sebagai berikut :

1. Komunikasi adalah suatu proses

2. Komunikasi adalah system

3. Komunikasi bersifat interaksi dan transaksi
4. Komunikasi dapat terjadi disengaja mapun tidak disengaja

Menurut Effendi (2014:173) metode komunikasi kerja adalah sebagai berikut :

1. Sumber mempunyai gagasan atau pemikiran

2. Dituangkan dalam bentuk kata-kata atau symbol

3. Disampaikan atau dikirimkan sebagai berita kepada penerima

4. Penerima menangkap simbol-simbol atau berita

5. Penerima mengirimkan kembali berupa umpan balik kepada pengirim

Menurut Mangkunegara (2016:146)

tahapan komunikasi kerja adalah :

1. Tahap pengembangan ide yaitu pengirim pesan ingin mengirimkan pesannya kepada penerima pesan.

2. Tahap encode yaitu tahap pemrosesan kata-kata yang disampaikan oleh pengirim pesan.

3. Tahap transmite yaitu tahap menggunakan metode dan salran komunikasi.

4. Tahap receive yaitu tahap penerima pesan yang disampaikan oleh pengirim pesan

5. Tahap decode yaitu tahap pesan yang diterima dapat dimengerti secara jelas.

6. Tahap use yaitu tahap dimana penerima pesan mampu menggunakan pesan yang diterimanya.

Menurut Muhammad (2015:85) indikator komunikasi kerja adalah :

1. Dukungan (Supportiveness)

Adalah bawahan mengamati bahwa hubungan komunikasi mereka dengan atasan membantu mereka membangun dan menjaga perasaan diri berharga dan penting.

2. Partisipasi membuat Keputusan

Melibatkan diri dalam upaya membuat keputusan.

3. Kepercayaan

Dapat dipercaya dan dapat menyimpan rahasia. 
4. Keterbukaan dan keterusterangan (Openess)

5. Artinya merupakan sikap jujur, rendah hati dan adil didalam menerima pendapat orang lain

6. Tujuan kinerja yang tinggi Maksudnya adalah pada tingkat mana tujuan kinerja dikomunikasikan dengan jelas kepada anggota organisasi.

Menurut Hasibuan

(2016:182)

faktor-faktor yang memengaruhi komunikasi kerja adalah sebagai berikut :

1. Hambatan semantik

2. Hambatan teknis

3. Hambatan biologis

4. Hambatan fisiologis

5. Hambatan kecakapan

\subsection{Kerangka Pemikiran}

Adapun kerangka pemikiran dalam penelitian ini sebagaimana dijelaskan pada gambar berikut ini :

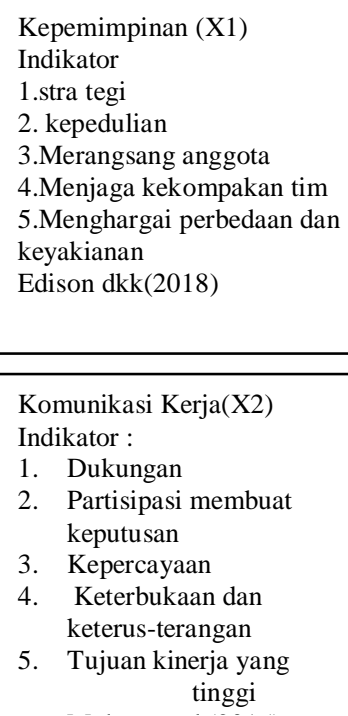

\section{METODOLOGI PENELITIAN}

\subsection{Rancangan Penelitian}

Rancangan penelitian dalam penelitian ini adalah sebagai berikut :

1. Melakukan survei atau mengunjungi lokasi penelitian dengan tujuan untuk mengetahui lokasi dan melakukan pendekatan.
2. Setelah itu Peneliti merumuskan masalah penelitian dan menentukan tujuan survei. Peneliti menentukan sebuah judul yang sesuai dengan masalah yang akan dibahas, yaitu Pengaruh Kepemimpinan dan Komunikasi Kerja Terhadap Kinerja ASN (Studi Kasus di 4 Kecamatan) Kota Lubuklinggau.

3. Menentukan konsep dan menggali kepustakaan tentang kepemimpinan dan komunikasi kerja serta kinerja pegawai.

4. Pengambilan sampel dan melakukan observasi.

5. Pembuatan kuisioner, pekerjaan lapangan (wawancara dan dokumentasi).

6. Pengolahan data kemudian menganalisis data dan pelaporan yang merupakan hasil dan ringkasan dari penelitian dan rekomendasi yang diberikan oleh peneliti.

\subsection{Populasi dan Sampel}

Adapun populasi dalam penelitian ini adalah ASN di 4 Kecamatan Kota Lubuklinggau sebanyak 55 orang.

Sampel jenuh adalah teknik penentuan sampel apabila semua anggota populasi digunakan sebagai sampel.Jadi sampel yang digunakan dalam penelitian ini sebanyak 55 orang responden.

\subsection{Teknik Pengumpulan Data}

Teknik pengumpulan data yang akan dipergunakan dalam penelitian ini adalah :

1. Observasi

Pengumpulan data dengan mengadakan pengamatan dan pencatatan secara sistematis terhadap objek yang diteliti.Dan dalam hal ini sementara peneliti mengobservasi keadaan yang ada di Kantor 4 Kecamatan Kota Lubuklinggau.

2. Kuesioner

Pengumpulan data dengan cara membagikan kuesioner kepada responden dalam hal ini adalah ASN di Kantor 4 Kecamatan di Kota Lubuklinggau. Kuesioner tersebut diisi dan dijawab kemudian dikembalikan kepada Peneliti.Yang berfungsi untuk 
mengetahui pengaruh kepemimpinan dan komunikasi kerja terhadap kinerja ASN di Kantor 4 Kecamatan Kota Lubuklinggau.

3. Dokumentasi

Dengan cara mencatat keterangan dan dokumen yang resmi. Teknik ini digunakan untuk mendukung data yang diperoleh baik melalui observasi maupun kuesioner.

\subsection{Hipotesis}

adalah:

$$
\text { Hipotesis dalam penelitian ini }
$$

1. Adanya pengaruh antara kepemimpinan terhadap kinerja ASN (StudiKasus di 4 Kecamatan) Kota Lubuklinggau.

2. Adanya pengaruh antara komunikasi kerja terhadap kinerja ASN (Studi Kasus di 4 Kecamatan) Kota Lubuklinggau.

3. Adanya pengaruh antara kepemimpinan dan komunikasi kerja terhadap kinerja ASN (Studi Kasus di 4 Kecamatan) Kota Lubuklinggau.

\section{HASIL DAN PEMBAHASAN}

1. Analisis Regresi Linier Sederhana, Analisis Koefisien Korelasi dan Analisis Uji $t \quad$ Variabel Kepemimpinan $\left(\mathrm{X}_{1}\right)$ Terhadap Kinerja ASN (Y)

Dari hasil perhitungan regresi linier sederhana, diperoleh nilai $\mathrm{b}_{1}=0,944$ sedangkan nilai $\mathrm{a}=3,782$. Kemudian nilai tersebut dimasukkan ke dalam persamaan regresi linier sederhana yaitu $\hat{Y}=3,782+$ $0,944 \mathrm{X}_{1}$ yang artinya jika variabel Kepemimpinan $\left(\mathrm{X}_{1}\right)$ tidak ada perubahan atau nilainya nol maka nilai variabel Kinerja ASN (Y) adalah sebesar 3,782. Koefisien regresi Kepemimpinan $\left(\mathrm{X}_{1}\right)$ sebesar $\mathrm{b}_{1}=$ 0,944 menyatakan bahwa setiap peningkatan Kepemimpinan $\left(\mathrm{X}_{1}\right)$ sebesar satu satuan maka hal tersebut akan meningkatkan Kinerja ASN (Y) sebesar 0,944. Sebaliknya, setiap penurunan Kepemimpinan $\left(\mathrm{X}_{1}\right)$ sebesar satu satuan maka hal tersebut akan menurunkan Kinerja ASN (Y) sebesar 0,944.

Nilai Koefisien korelasi diperoleh angka $\mathrm{R}$ sebesar 0,922 .Hal ini menunjukkan bahwa variabel Kepemimpinan $\left(\mathrm{X}_{1}\right)$ terhadap Kinerja ASN (Y) mempunyai hubungan yang sangat kuat.Sedangkan arah hubungan adalah positif karena nilai $\mathrm{R}$ positif.

Dari perhitungan Uji t diketahui hasil $t_{\text {hitung }}$ menunjukkan bahwa variabel Kepemimpinan $\left(\mathrm{X}_{1}\right)$ mempunyai nilai $\mathrm{t}_{\mathrm{itung}}$ sebesar 17,346 lebih besar dibandingkan dengan nilai tabel pada taraf nyata sebesar 2,004 atau dapat dikatakan variabel Kepemimpinan $\left(\mathrm{X}_{1}\right)$ berpengaruh signifikan terhadap variabel Kinerja ASN (Y). Berdasarkan hasil pengolahan data diatas dapat dibuktikan bahwa $\mathrm{H}_{1}=$ Kepemimpinan $\left(\mathrm{X}_{1}\right)$ berpengaruh positif Terhadap Kinerja ASN (Y).

Hipotesis pertama yang menyatakan bahwa terdapat pengaruh signifikan secara parsial antara Kepemimpinan $\left(\mathrm{X}_{1}\right)$ terhadap Kinerja ASN (Y).Berdasarkan hasil pengolahan data, nilai $\mathrm{t}_{\text {hitung }}$ untuk Kepemimpinan $\left(\mathrm{X}_{1}\right)$ adalah 17,346 sedangkan $t_{\text {tabel }}$ sebesar 2,004.Dari data tersebut terdapat bahwa $t_{\text {hitung }}$ lebih besar dari $\mathrm{t}_{\text {tabel }}\left(\mathrm{t}_{\text {hitung }}>\mathrm{t}_{\text {tabel }}\right)$.Maka dapat disimpulkan bahwa secara parsial variabel Kepemimpinan $\left(\mathrm{X}_{1}\right)$ berpengaruh signifikan positif terhadap variabel Kinerja ASN (Y).

\section{AnalisisRegresi Linier Sederhana, Analisis Koefisien Korelasi dan Analisis Uji $t \quad$ Variabel KomunikasiKerja $\left(\mathbf{X}_{2}\right)$ Terhadap Kinerja ASN (Y)}

Dari hasil perhitungan regresi linier sederhana, diperoleh nilai $\mathrm{b}_{2}=0,993$ sedangkan nilai $\mathrm{a}=0,526$. Kemudian nilai tersebut dimasukkan ke dalam persamaan regresi linier sederhana yaitu $\hat{Y}=0,526+$ $0,993 \mathrm{X}_{2}$ yang artinya jika Komunikasi Kerja $\left(\mathrm{X}_{2}\right)$ tidak ada perubahan atau nilainya nol maka nilai variabel Kinerja ASN (Y) sebesar 0,526. Koefisien regresi Komunikasi Kerja $\left(\mathrm{X}_{2}\right)$ sebesar $\mathrm{b}_{2}=0,993$ menyatakan bahwa setiap peningkatan Komunikasi Kerja $\left(\mathrm{X}_{2}\right)$ sebesar satu satuan maka hal tersebut akan meningkatkan Kinerja ASN (Y) sebesar 0,993. Sebaliknya, setiap penurunan Komunikasi Kerja $\left(\mathrm{X}_{2}\right)$ sebesar satu satuan maka hal tersebut akan menurunkan Kinerja ASN (Y) sebesar 0,993.

Nilai koefisien korelasi diperoleh angka $\mathrm{R}$ sebesar 0,903.Hal ini menunjukkan bahwa variabel Komunikasi Kerja $\left(\mathrm{X}_{2}\right)$ terhadap Kinerja ASN (Y) mempunyai hubungan yang sangat kuat.Sedangkat arah 
hubungan adalah positif karena nilai $\mathrm{R}$ positif.

Dari perhitungan Uji t diketahui hasil $t_{\text {hitung }}$ menunjukkan bahwa variabel Komunikasi Kerja $\left(\mathrm{X}_{2}\right)$ mempunyai nilai $\mathrm{t}_{\text {hitung }}$ sebesar 15,299 lebih besar dibandingkan dengan nilai $t_{\text {tabel }}$ pada taraf nyata sebesar 2,004 atau dapat dikatakan variabel Komunikasi Kerja $\left(\mathrm{X}_{2}\right)$ berpengaruh signifikan terhadap variabel Kinerja ASN (Y). Berdasarkan hasil pengolahan data diatas dapat dibuktikan bahwa $\mathrm{H}_{2}=$ Komunikasi Kerja $\left(\mathrm{X}_{2}\right)$ berpengaruh positif terhadap Kinerja ASN (Y).

Hipotesis kedua yang menyatakan bahwa terdapat pengaruh signifikan secara parsial antara Komunikasi Kerja $\left(\mathrm{X}_{2}\right)$ terhadap Kinerja ASN (Y).Berdasarkan hasil pengolahan data, nilai $t_{\text {hitung }}$ untuk Komunikasi Kerja $\left(\mathrm{X}_{2}\right)$ adalah 15,299 sedangkan $t_{\text {tabel }}$ sebesar 2,004.Dari data tersebut terdapat bahwa $t_{\text {hitung }}$ lebih besar dari $\mathrm{t}_{\text {tabel }}$ ( $\left.\mathrm{t}_{\text {hitung }}>\mathrm{t}_{\text {tabel }}\right)$.Maka dapat disimpulkan bahwa secara parsial variabel Komunikasi Kerja $\left(\mathrm{X}_{2}\right)$ berpengaruh signifikan positif terhadap variabel Kinerja ASN (Y).

\section{Analisis Regresi Linier Berganda, Analisis Koefisien Determinasi $\left(\mathbf{R}^{2}\right)$, dan Analisis Uji F Variabel Kepemimpinan ( $\left.\mathbf{X}_{1}\right)$ dan Komunikasi Kerja $\left(\mathbf{X}_{2}\right)$ Terhadap Kinerja ASN (Y)}

Dari persamaan regresi $\hat{Y}=0,488+$ $0,617 X_{1}+0,379 X_{2}$ menggunakan nilai konstanta sebesar $\mathrm{a}=0,488$ menyatakan bahwa jika Kepemimpinan $\left(\mathrm{X}_{1}\right)$ dan Komunikasi Kerja $\left(\mathrm{X}_{2}\right)$ tidak ada perubahan atau nilainnya nol maka nilai variabel Kinerja ASN (Y) adalah sebesar 0,488. Koefisien regresi Kepemimpinan $\left(\mathrm{X}_{1}\right)$ sebesar $b_{1}=0,617$ menyatakan bahwa setiap peningkatan Kepemimpinan $\left(\mathrm{X}_{1}\right)$ sebesar satu satuan maka hal tersebut akan meningkatkan Kinerja ASN (Y) sebesar 0,617. Demikian juga sebaliknya jika ada penurunan Kepemimpinan $\left(\mathrm{X}_{1}\right)$ sebesar satu satuan maka akan menurunkan Kinerja ASN (Y) sebesar 0,617. Koefisien regresi Komunikasi Kerja $\left(\mathrm{X}_{2}\right)$ sebesar $\mathrm{b}_{2}=0,379$ menyatakan bahwa setiap peningkatan Komunikasi Kerja $\left(\mathrm{X}_{2}\right)$ sebesar satu satuan maka hal tersebut akan meningkatkan Kinerja ASN (Y) sebesar 0,379. Demikian juga sebaliknya jika ada penurunan Komunikasi Kerja $\left(\mathrm{X}_{2}\right)$ sebesar satu satuan maka akan menurunkan Kinerja ASN (Y) sebesar 0,379.

Nilai koefisien determinasi diperoleh angka $\mathrm{R}$ Square $\left(\mathrm{R}^{2}\right)$ sebesar 0,867 atau $86,7 \%$. Nilai tersebut memberi pengertian bahwa Kepemimpinan $\left(\mathrm{X}_{1}\right)$ dan Komunikasi Kerja $\left(\mathrm{X}_{2}\right)$ memberikan sumbangan pengaruh sebesar 86,7\% terhadap Kinerja ASN (Y). Sedangkan sisanya sebesar 13,3 \% dipengaruhi oleh variabel lain yang tidak termasuk dalam penelitian ini. Dengan menggunakan tingkat keyakinan 95\%, a = $5 \%$, df1 (jumlah variabel -1$)=2$ dan df $2(n$ $-\mathrm{k}-1)$ atau $(55-2-1)=52$. Nilai $F_{\text {hitung }}$ adalah sebesar 169,645 dengan tingkat signifikansi 0,000.Dimana jika $F_{\text {hitung }}>F_{\text {tabel }}$ maka Ho ditolak dan $\mathrm{Ha}$ diterima.Sebaliknya, jika $F_{\text {hitung }}<F_{\text {tabel }}$ maka Ho diterima dan Ha ditolak.Pada penelitian ini ternyata $F_{\text {hitung }}(169,645)>F_{\text {tabel }}(3,175)$, artinya Ho ditolak dan Ha diterima.Hal ini menunjukkan ada pengaruh yang signifikan antara variabel Kepemimpinan $\left(\mathrm{X}_{1}\right)$ dan Komunikasi Kerja $\left(\mathrm{X}_{2}\right)$ Terhadap Kinerja ASN (Y). Berdasarkan hasil pengolahan data diatas dapat dibuktikan bahwa $\mathrm{H}_{3}=$ Kepemimpinan $\left(\mathrm{X}_{1}\right)$ dan Komunikasi Kerja $\left(\mathrm{X}_{2}\right)$ berpengaruh positif terhadap Kinerja $\operatorname{ASN}(\mathrm{Y})$.

Hipotesis ketiga yang menyatakan bahwa terdapat pengaruh signifikan secara bersama-sama antara Kepemimpinan $\left(\mathrm{X}_{1}\right)$ dan Komunikasi Kerja $\left(\mathrm{X}_{2}\right)$ berpengaruh positif terhadap Kinerja ASN (Y).Berdasarkan hasil pengolahan data, nilai $F_{\text {hitung }}$ adalah 169,645 sedangkan $F_{\text {tabel }}$ sebesar 3,175.Dari data tersebut terlihat bahwa $F_{\text {hitung }}$ lebih besar dari $F_{\text {tabel }}\left(F_{\text {hitung }}>\right.$ $\mathrm{F}_{\text {tabel }}$. Maka dapat disimpulkan bahwa secara simultan variabel Kepemimpinan $\left(\mathrm{X}_{1}\right)$ dan Komunikasi Kerja $\left(\mathrm{X}_{2}\right)$ berpengaruh signifikan positif terhadapKinerja ASN (Y).

\section{KESIMPULAN}

Berdasarkan penelitian dari hasil analisis sesuai dengan rumusan masalah penelitian, maka peneliti dapat menyimpulkan bahwa:

1. Variabel Kepemimpinan $\left(\mathrm{X}_{1}\right)$ berpengaruh signifikan terhadap Kinerja ASN (Y) hal ini dapat dilihat dari hipotesis pertama yang menyatakan 
bahwa terdapat pengaruh signifikan secara parsial antara Kepemimpinan $\left(\mathrm{X}_{1}\right)$ terhadap Kinerja ASN (Y). Berdasarkan hasil pengolahan data, nilai $\mathrm{t}_{\text {hitung }}$ untuk Kepemimpinan $\left(\mathrm{X}_{1}\right)$ adalah 17,346 sedangkan $t_{\text {tabel }}$ sebesar 2,004.

Dari data tersebut terdapat bahwa $t_{\text {hitung }}$ lebih besar dari $t_{\text {tabel }}\left(t_{\text {hitung }}>t_{\text {tabel }}\right)$. Maka dapat disimpulkan bahwa secara parsial variabel Kepemimpinan $\left(\mathrm{X}_{1}\right)$ berpengaruh signifikan positif terhadap variabel Kinerja ASN (Y).

2. Variabel KomunikasiKerja $\left(\mathrm{X}_{2}\right)$ berpengaruh signifikan terhadap Kinerja ASN (Y) hal ini dapat dilihat dari hipotesis kedua yang menyatakan bahwa terdapat pengaruh signifikan secara parsial antara KomunikasiKerja $\left(\mathrm{X}_{2}\right)$ terhadap Kinerja ASN (Y). Berdasarkan hasil pengolahan data, nilai $\mathrm{t}_{\text {hitung }}$ untuk KomunikasiKerja $\left(\mathrm{X}_{2}\right)$ adalah 15,299 sedangkan $t_{\text {tabel }}$ sebesar 2,004 . Dari data tersebut terdapat bahwa $t_{\text {hitung }}$ lebih besar dari $t_{\text {tabel }}\left(t_{\text {hitung }}>t_{\text {tabel }}\right)$. Maka dapat disimpulkan bahwa secara parsial variabel KomunikasiKerja $\left(\mathrm{X}_{2}\right)$ berpengaruh signifikan positif terhadap variabel Kinerja ASN (Y).

3. Variabel Kepemimpinan $\left(\mathrm{X}_{1}\right)$ dan KomunikasiKerja $\left(\mathrm{X}_{2}\right)$ berpengaruh signifikan terhadap Kinerja ASN (Y) hal ini dapat dilihat dari hipotesis ketiga yang menyatakan bahwa terdapat pengaruh signifikan secara bersamasama antara Kepemimpinan $\left(\mathrm{X}_{1}\right)$ dan KomunikasiKerja $\left(\mathrm{X}_{2}\right)$ berpengaruh positif terhadap Kinerja ASN (Y). Berdasarkan hasil pengolahan data, nilai $F_{\text {hitung }}$ adalah 169,645 sedangkan $F_{\text {tabel }}$ sebesar 3,175. Dari data tersebut terlihat

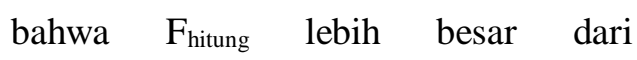
$\mathrm{F}_{\text {tabel }}\left(\mathrm{F}_{\text {hitung }}>\quad \mathrm{F}_{\text {tabel }}\right)$. Maka dapat disimpulkan bahwa secara simultan variabel Kepemimpinan $\left(\mathrm{X}_{1}\right)$ dan KomunikasiKerja $\left(\mathrm{X}_{2}\right)$ berpengaruh signifikan positif terhadap Kinerja ASN (Y).

\section{SARAN}

Dari hasil kesimpulan yang telah diambil sebelumnya, dapat diajukan beberapa saran yaitu:

1. Kepemimpinan

Pimpinan seyogyanya memiliki strategi yang jelas dan realitas di dalam organisasi serta memotivasi agar kekompakkan tim tetap solid dalam upaya pencapaian tujuan organisasi.

2. KomunikasiKerja

Dari hasil analisis diketahui bahwa komunikasi kerja memiliki hubungan yang sangat kuat terhadap terhadap kinerja ASN, hal ini perlu mendapat perhatian organisasi, khususnya bagi pimpinan agar dapat melakukan tugasnya dengan baik lagi, dalam hal ini adalah berkomunikasi dan merepkan sikap saling percaya kepada ASN dalam menjalankan tugasnya, karena semakin erat hubungannya maka akan semakin baik pula kinerja ASN.

3. Kinerja ASN

Berdasarkan analisis pula diketahui bahwa variabel kepemimpinan dan komunikasi kerja merupakan variabel yang sama-sama berpengaruh dominan terhadap kinerja ASN di 4 Kecamatan Kota Lubuklinggau, berarti kepemimpinan dan komunikasi merupakan salah satu yang sangat penting bagi kinerja ASN, seyogyanya bagi pimpinan agar terus meningkatkan komunikasinya dan tetap memperhatikan secara terus menerus dengan tidak melupakan variabel lain yang juga sama penting.

4. Kepemimpinan dan Komunikasi Kerja Terhadap Kinerja ASN

Strategi kepemimpinan dalam mengatasi pegawai yang jelas dan realitas serta terciptanya proses komunikasi kerja sesama pegawai yang kondusif sangat mempengaruhi dan dapat meningkatkan kinerja ASN secara optimal. 
VII. DAFTAR PUSTAKA

[1] Arikunto, Suharsimi, 2014. Prosedur Penelitian. Edisi Revisi VI. Jakarta : Rineka Cipta.

[2] Busro, Muhammad. 2018. Teori-teori Manajemen Sumber Daya Manusia. Cetakan ke Satu.Jakarta : Penerbit Kencana.

[3] Edison, Emron, dkk. 2018. Manajemen Sumber Daya Manusia Strategi dan Perubahan dalam Rangka Meningkatkan Kinerja Pegawai dan Organisasi.Cetakan ketiga.Bandung : Alfabeta.

[4] Effendi, Usman, 2014. Asas Manajemen. Jakarta : Penerbit Rajawali Pers.

[5] Fahmi, Irham. 2014. Manajemen Teori, Kasus, dan Solusi.Cetakan ketiga.Bandung : CV Alfabeta.

[6] Hasibuan, Malayu S.P. 2016. Manajemen Sumber Daya Manusia Revisi. Cetakan ke Dua puluh.Jakarta. Penerbit : PT. Bumi Aksara.

[7] Kasmir. 2018. Manajemen Sumber Daya Manusia Teori dan Praktik. Cetakan Ke Empat. Jakarta : Penerbit PT. Raja Grafindo Persada.

[8] Mangkunegara, Anwar Prabu. 2016. Manajemen Sumber Daya Manusia Perusahaan. Cetakan Ke Tiga Belas. Bandung : PT Remaja Rosda Karya.

[9] Minh Ha, Ngunyen. 2014. The Influence of Leadership behaviors on Employee Performance in the Context of Software Companiesin Vietnam. Journal International Issue 01 Volume 12.

[10] Muhammad, Arni. 2015. Komunikasi Organisasi. Cetakan ke Emoat belas.Jakarta : Bumi Aksara.

[11] Muhidin, Sambas Ali, dkk. 2017. Analisis Korelasi, Regresi, dan Jalur
Dalam

Penelitian.

Cetakan

ketiga.Bandung : CV Pustaka Setia. 